\title{
Subcontractor Selection Review Industry XYZ With Analytic Network Process (ANP) Method
}

\author{
Ardianto Septian \\ Department of Technology Management, Institut Teknologi Sepuluh Nopember, Surabaya \\ e-mail: ardianto0951@gmail.com
}

\begin{abstract}
In the steel construction of the Kendari Newport Container Facilitiy and Utilities Project's which was undertaken by the XYZ Contractor, there was a problem. Until the contractor issued a warning letter against the selected subcontractor because of delays in work. This research aims to examine the stages of selection subcontractors whether there is an error in decision making that causes delays work by subcontractor that selected as a partners.Therefore, decision makers need right selection methods. Multi Criteria Decision Making (MCDM) method is an appropriate method for the selection of several criteria. One of them is the Analytic Network Process (ANP) -Risk Assessment method.Based on the analysis using the ANP method, sub-criteria with the highest priority weight is the bid price with a weight of $17.13 \%$, The final results of the overall analysis showed that subcontractor $B$ get in first place with a score 2,97 . In this research subcontractor $B$ has the highest value, which means that the subcontractor is feasible and accordance with the assessment of XYZ Company to be a partner to doing the steel construction work in this case study.
\end{abstract}

Keywords-ANP, MCDM, Risk Assessment, Subcontractor selection.

\section{INTRODUCTION}

$\mathrm{E}$ ACH project has a complex complexity at each stage. The success of a project can be realized from a good initial stage process, a mature and structured planning process to a good process at the time of implementation and also a control that functions as a checker for each work.

On the part of the selection committee in a decisionmaking project when selecting subcontractors in the project becomes very important so as not to choose the wrong partner. Selection right subcontractor in the project affects the success of the project, minimizes risk, creates a good working atmosphere in the project, and also affects the optimization of expenses paid by the main contractor to the subcontractor. The selection of subcontractors must be carefully considered and also look at several aspects, the selection of subcontractors based on just one criterion such as price, does not guarantee that the subcontractor is competent in doing the work and responsibilities.

The selection process can actually be done alone by a company leader to selecting partners, but the selection of partners should not be done alone. This is so that the selection process includes other parties with the aim of minimizing selection errors, it makes the selection of alternative subcontractor partners more objective. Therefore, decision makers in a company need an appropriate selection method in solving complex problems with the selection criteria of appropriate and quality subcontractors so that risks can be minimized, and subcontractors can support the main employer / contractor in project completion

In XYZ Compnay often uses subcontractors as executors for certain jobs. There are various kinds of risks if one chooses to choose a subcontractor partner. The contractor selection process is often subjective, sometimes inconsistent with the initial requirements, the selection process is often only by presentation without a scoring process so that there will be great inconsistencies at the time of the assessment.

In the case of steel construction project at the Kendari Newport Container Building and Utility Facility Project undertaken by the XYZ Contractor there was a problem, until the Contractor issued a Warning Letter to the designated subcontractor due to delays in work

The selection of subcontractors is a multi-criteria issue which includes quantitative and qualitative factors. Some of the criteria that influence the selection of subcontractors are quantitative and qualitative. Therefore we need a method that can align both of them in the measurement.

Multi criteria decision making method (MCDM) is a decision making method to determine the best alternative from a number of alternatives based on certain criteria. One method that can be used for multi-criteria selection is to use the Analytic Network Process (ANP) method.

Analytic network process (ANP) is a measurement method with multiple criteria used to obtain priority scales from individual valuation results using absolute value scales or from actual normalized measurement results.

This study aims to examine at the subcontractor selection stage whether there are errors when making decisions that cause delays in the work of the selected subcontractor.

\section{LITERATURE REVIEW}

According to D. J. Watt, B. Kayis and Willey (2010) Research on criteria for the selection of contractors in projects and service industries in Australia. Using two approaches of literature study and direct survey. Conduct a review of 31 previous research literature. The survey was conducted using a descriptive survey method (exploratory survey), through questionnaires and interviews of 58 respondents with senior managers who have experience in the contractor selection process. The results of the study obtained 6 categories of general criteria and 4 categories of special criteria [5].

In the research on subcontractors based on the AHP method applied by Thomas L. Saaty (1999) to several companies in small, medium to large scale. There were 30 respondents who were used for the selection of criteria weight that were different from previous studies. The weighting 


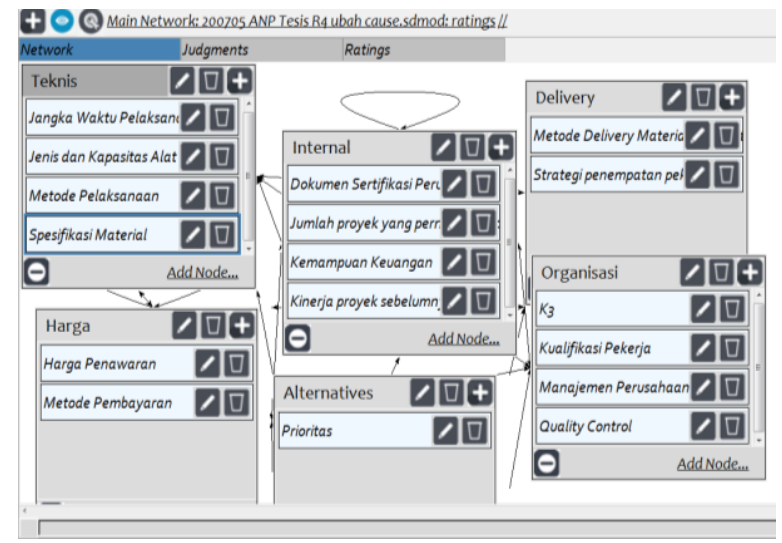

Figure 1. Implementation ANP on Superdecision software.

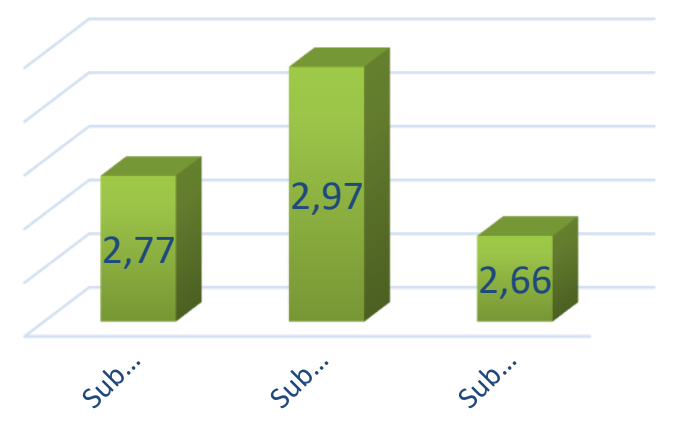

Figure 2. Final Score of Subcontractor's graph.

criteria for the results of the survey are Cost (28.7\%), Quality $24.8 \%$, production $18.8 \%$, financial $15.7 \%$, Synergy $12 \%$. And performed on 3 alternative subcontractors so that subcontractor A was chosen with the highest weight [3].

Research conducted by A. E. Cengiz, O. Aytekin, I. Ozdemir, H. Kusan and A. Cabuk, conducted a study of the criteria for selecting suppliers engaged in supplying wall materials in Turkey, finishing facades (Cladding), and roofing materials. Using the Analytical Network Process (ANP) method in his research. Responsibility Questionnaire addressed to professionals as construction companies, universities, and government. Questionnaires given to professionals after that are carried out statistical tests to get priority weights. Implemented against 3 alternative suppliers with 10 main criteria and 19 sub-criteria [2].

\section{MODEL FOR MULTI-CRITERIA DECISION MAKING}

\section{A. Analytic Network Process (ANP)}

Analytic network process (ANP) is a measurement method with multiple criteria used to obtain priority scales from individual valuation results using absolute value scales or from actual normalized measurement results. This method is a development of the Analytical Hierarchy Process (AHP) method.

Thomas L. Saaty developed the AHP method as a decision making technique that can be used to choose a complex decision. Using pairwise comparison techniques and expert judgment to determine the priority scale of each decision
Table 1.

Risk Qualitative process

\begin{tabular}{ccc}
\hline \hline Inputs & Tools and Techniques & Outputs \\
\hline Organizational & Risk probability and & \\
process asset & impact assessment & \\
Project scope & Probability and impact & \\
statement & matrix & Risk register \\
Risk management & Risk data quality & (update) \\
plan & assessment & \\
Risk register & Risk categorization & \\
& Risk urgency & \\
& assessment & \\
\hline \hline
\end{tabular}

criterion and an assessment of alternative decisions [3].

\section{B. Risk Assessment (Qualitative)}

Risk assessment is carried out with the aim to determine the dimensions, size, and weights in relation to the type of risk, the impact caused, and the likelihood of the risk occurring [1].

From the identification of the risks obtained, the risk is further analyzed to determine the risk probability and its impact, as well as its risk category and risk urgency. This qualitative analysis process can use the methods: risk probability impact assessment, probability \& impact matrix, risk data quality assessment, risk category assessment, and risk urgency assessment. This qualitative risk analysis will result in an updated register register as shown in the Table 1.

Qualitative risk analysis aims to determine the likelihood of potential impacts from the risks identified earlier. According to R. C. Walke (2011) the following stages are for conducting qualitative risk analysis using QRA Sheet (Qualitative Risk Analysis Sheet). This stage is to make a Qualitative risk analysis sheet form that is distributed to the team which contains the probabilities and impacts of each identified risk [4].

\section{IDENTIFIED DECISSION CRITERIA- SUBCRITERIA}

In this section stage, the data that has been obtained are To identify criteria and subcriteria for selecting subcontractor are getting from two ways, first getting from reviewing literature that has topic alternatif construction selection and then ask expert judgement to know local criteria that effect in subcontractor selection (Table 2).

From distribution of questionnaires to expert jugdement, there are some changes, especially in the decision subcriteria. Initially there were 15 sub-criteria in the literature study, there were the addition of 2 decision sub-criteria, namely the company certification and capability in Health and Safety (K3), while for the sub-criteria The location / branch of the nearest company was reduced because from the results of the distribution of questionnaires $55 \%$ of respondents disagreed with the sub-criteria used in consideration of the decision to select the subcontractor. The results of the identification of the Criteria and Sub-criteria are shown in Table 2. 
Table 2.

Identified Criteria

\begin{tabular}{|c|c|c|c|c|}
\hline No & Criteria & Subcriteria & $\begin{array}{c}\text { Literature } \\
\text { review }\end{array}$ & $\begin{array}{c}\text { Expert } \\
\text { Judgement }\end{array}$ \\
\hline \multirow{3}{*}{1} & \multirow{3}{*}{ Cost } & Bid Price & $\sqrt{ }$ & $\sqrt{ }$ \\
\hline & & Payment Method & $\sqrt{ }$ & $\sqrt{ }$ \\
\hline & & Material Spesification & $\sqrt{ }$ & $\sqrt{ }$ \\
\hline \multirow{4}{*}{2} & \multirow{4}{*}{ Technical } & Construction method & $\sqrt{ }$ & $\sqrt{ }$ \\
\hline & & Construction Period & $\sqrt{ }$ & $\sqrt{ }$ \\
\hline & & Type and Tools Capacity & $\sqrt{ }$ & $\sqrt{ }$ \\
\hline & & Financial Ability & $\sqrt{ }$ & $\sqrt{ }$ \\
\hline \multirow{4}{*}{3} & \multirow{4}{*}{ Internal } & Number of project that have done & $\sqrt{ }$ & $\sqrt{ }$ \\
\hline & & Project Exerience & $\sqrt{ }$ & $\sqrt{ }$ \\
\hline & & Company certification & - & $\sqrt{ }$ \\
\hline & & Worker Cualification & $\sqrt{ }$ & $\sqrt{ }$ \\
\hline \multirow{4}{*}{4} & \multirow{4}{*}{ Organization } & Quality Control & $\sqrt{ }$ & $\sqrt{ }$ \\
\hline & & Company Management & $\sqrt{ }$ & $\sqrt{ }$ \\
\hline & & $\mathrm{K} 3$ & - & $\sqrt{ }$ \\
\hline & & Company location/ nearest branch & $\sqrt{ }$ & - \\
\hline \multirow[t]{2}{*}{5} & Delivery & Delivery material and tools method & $\sqrt{ }$ & $\sqrt{ }$ \\
\hline & & Worker placement strategy & $\sqrt{ }$ & $\sqrt{ }$ \\
\hline
\end{tabular}

Table 3.

ANP Weight priority result from Identified Criteria

\begin{tabular}{|c|c|c|c|}
\hline No & Subcriteria & Normalized By Cluster & Limiting \\
\hline 1 & Bid Price & $78.38 \%$ & $17.13 \%$ \\
\hline 2 & Material Spesification & $33.51 \%$ & $13.03 \%$ \\
\hline 3 & Construction Method & $24.81 \%$ & $9.65 \%$ \\
\hline 4 & Construction Period & $24.31 \%$ & $9.45 \%$ \\
\hline 5 & Company Certification & $36.43 \%$ & $7.04 \%$ \\
\hline 6 & Type and Tools Capacity & $17.38 \%$ & $6.76 \%$ \\
\hline 7 & Financial ability & $30.69 \%$ & $5.93 \%$ \\
\hline 8 & Quality Control & $35.93 \%$ & $5.40 \%$ \\
\hline 9 & Payment Method & $21.62 \%$ & $4.72 \%$ \\
\hline 10 & Number of Project Have Done & $23.20 \%$ & $4.48 \%$ \\
\hline 11 & Worker Qualification & $27.17 \%$ & $4.08 \%$ \\
\hline 12 & Material and Tools Delivery & $81.90 \%$ & $4.02 \%$ \\
\hline 13 & Company Management & $24.31 \%$ & $3.65 \%$ \\
\hline 14 & K3 & $12.58 \%$ & $1.89 \%$ \\
\hline 15 & Project Experience & $9.68 \%$ & $1.87 \%$ \\
\hline 16 & Worker Placement strategy & $18.10 \%$ & $0.89 \%$ \\
\hline
\end{tabular}

\section{IMPLEMENTATION OF ANP-RISK ASSESMENT IN CASE STUDY}

To completing process all data in this research, the first stages is ANP scoring to all subcriteria to get result of score of subcontractor based on ANP and then Qualitative risk scoring to all subcontractors from Impact and probability perception of all respondent and final score from subcontractors, that score from divide ANP score with Risk score with each weight priority company needs, weighting information getting from interview with management of the company in this case study.

\section{A. ANP Process from Identified Criteria}

From Identified criteria-subcriteria next process is process data from respondent whoe they are employee of Company $\mathrm{XYZ}$ that has capability for selection subcontractor process. Respondents in this study consisted of 4 people the parties who selectedi of subcontractors at the time of the project in Kendari Newport Building and Utility Facility Project. One of the respondents in this study, there project managers who are the leader in the project of the Kendari Newport Building Facilities and Utility Project, which was a representative of XYZ Company.

\section{1) Build a Model from Identified Relationship}

From the results of the confirmation of identifying criteria and sub-criteria, the next step is the process of identifying the relationship between the decision sub-criteria. To get the results, a questionnaire was distributed about the relationship between decision sub-criteria to respondents. In identifying the relationship between criteria / sub-criteria there are two types of relationships between the criteria / sub-criteria, namely inner dependence and outer dependence. Inner dependence is a relationship that occurs between sub-criteria within the same criteria. Outer dependence relationships are relationships that occur between sub-criteria on different criteria. In this research use Super Decision software to complete ANP process (Figure 1).

\section{2) Pairwise Comparison}

ANP process in this research using Super Decision Aplication. The Result from ANP process to all identified subcriteria are shown in Table 3.

Five subcriteria with the largest weight are at the Bid price with a weight value of $17.13 \%$, the second is a material specification with a weight value of $13.03 \%$, then an Construction method of $9.65 \%$, the fourth is a Construction period with aweight of $9,45 \%$, and the fifth largest subcriteria 
Table 4.

ANP Result of scoring alternative Subcontractors

\begin{tabular}{|c|c|c|c|c|c|c|c|c|}
\hline \multirow{2}{*}{ No } & \multirow{2}{*}{ Subcriteria } & \multirow{2}{*}{ Weight } & \multicolumn{2}{|c|}{ Subcontractor A } & \multicolumn{2}{|c|}{ "Subcontractor B } & \multicolumn{2}{|c|}{ Pubcontractor $\mathrm{C}$} \\
\hline & & & Score & Total & Score & Total & Score & Total \\
\hline 1 & Bid Price & $17.13 \%$ & 2 & 0.42 & 5 & 0.81 & 4 & 0.69 \\
\hline 2 & Payment Method & $4.72 \%$ & 4 & 0.18 & 6 & 0.27 & 4 & 0.19 \\
\hline 3 & Material Spesification & $13.03 \%$ & 5 & 0.60 & 4 & 0.49 & 3 & 0.39 \\
\hline 4 & Construction method & $9.65 \%$ & 4 & 0.39 & 3 & 0.31 & 3 & 0.30 \\
\hline 5 & Construction Period & $9.45 \%$ & 5 & 0.45 & 5 & 0.45 & 5 & 0.45 \\
\hline 6 & Type and Tools Capacity & $6.76 \%$ & 6 & 0.40 & 6 & 0.41 & 4 & 0.27 \\
\hline 7 & Financial Ability & $5.93 \%$ & 3 & 0.17 & 6 & 0.34 & 5 & 0.33 \\
\hline 8 & Number of project that have done & $4.48 \%$ & 4 & 0.18 & 3 & 0.13 & 3 & 0.15 \\
\hline 9 & Project Exerience & $1.87 \%$ & 4 & 0.08 & 5 & 0.09 & 6 & 0.11 \\
\hline 10 & Company certification & $7.04 \%$ & 4 & 0.30 & 4 & 0.28 & 4 & 0.32 \\
\hline 11 & Worker Cualification & $4.08 \%$ & 3 & 0.14 & 4 & 0.17 & 4 & 0.15 \\
\hline 12 & Quality Control & $5.40 \%$ & 4 & 0.23 & 4 & 0.23 & 5 & 0.26 \\
\hline 13 & Company Management & $3.65 \%$ & 4 & 0.15 & 6 & 0.21 & 5 & 0.20 \\
\hline 14 & $\mathrm{~K} 3$ & $1.89 \%$ & 3 & 0.06 & 4 & 0.07 & 4 & 0.07 \\
\hline 15 & Delivery material and tools method & $4.02 \%$ & 5 & 0.19 & 6 & 0.23 & 5 & 0.20 \\
\hline \multirow[t]{2}{*}{16} & Worker placement strategy & $0.89 \%$ & 5 & 0.04 & 4 & 0.04 & 5 & 0.04 \\
\hline & Total & $100 \%$ & \multicolumn{2}{|c|}{3.97} & \multicolumn{2}{|c|}{4.52} & \multicolumn{2}{|c|}{4.09} \\
\hline
\end{tabular}

Table 5.

Qualitative Risk Analysis of identification subcriteria

\begin{tabular}{|c|c|c|c|c|c|c|c|c|}
\hline \multirow[b]{2}{*}{ No } & \multirow[b]{2}{*}{ Sub Criteria } & \multirow[b]{2}{*}{ Impact } & \multicolumn{2}{|c|}{ Subcontractor A } & \multicolumn{2}{|c|}{ Subcontractor B } & \multicolumn{2}{|c|}{ Subcontractor C } \\
\hline & & & 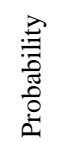 & 豞 & 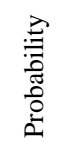 & 完 & 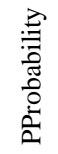 & 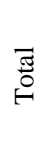 \\
\hline 1 & Bid Price & 2 & 2 & 4 & 2 & 4 & 2 & 4 \\
\hline 2 & Payment Method & 1 & 1 & 1 & 1 & 1 & 2 & 2 \\
\hline 3 & Material Spesification & 2 & 2 & 4 & 2 & 4 & 1 & 2 \\
\hline 4 & Construction method & 3 & 1 & 3 & 2 & 6 & 1 & 3 \\
\hline 5 & Construction Period & 3 & 2 & 6 & 1 & 3 & 2 & 6 \\
\hline 6 & Type and Tools Capacity & 2 & 1 & 2 & 1 & 2 & 2 & 4 \\
\hline 7 & Financial Ability & 1 & 1 & 1 & 2 & 2 & 2 & 2 \\
\hline 8 & Number of project that have done & 1 & 1 & 1 & 1 & 1 & 1 & 1 \\
\hline 9 & Project Exerience & 2 & 1 & 2 & 1 & 2 & 2 & 4 \\
\hline 10 & Company certification & 1 & 1 & 1 & 2 & 2 & 1 & 1 \\
\hline 11 & Worker Cualification & 1 & 2 & 2 & 1 & 1 & 2 & 2 \\
\hline 12 & Quality Control & 3 & 1 & 3 & 1 & 3 & 2 & 6 \\
\hline 13 & Company Management & 1 & 2 & 2 & 2 & 2 & 1 & 1 \\
\hline 14 & K3 & 2 & 2 & 4 & 2 & 4 & 3 & 6 \\
\hline 15 & Delivery material and tools method & 2 & 2 & 4 & 1 & 2 & 2 & 4 \\
\hline \multirow[t]{2}{*}{16} & Worker placement strategy & 1 & 1 & 1 & 3 & 3 & 1 & 1 \\
\hline & & & \multicolumn{2}{|c|}{41} & \multicolumn{2}{|c|}{42} & \multicolumn{2}{|c|}{49} \\
\hline
\end{tabular}

is a company certification which is $7.04 \%$. The biggest gap between sub-criteria is in the first and second ranks because there are many outer dependencies that affect the sub-criteria until the sub-criteria rise during the weighting process using the ANP method Super Decision software.

\section{3) ANP Score for Alternative Subcontractors}

ANP score for alternative subcontractors are shown in Table 4.

\section{B. Risk Assessment from Identified Criteria}

The results of each contractor's risk assessment are obtained from the impact and probability probability questionnaire for each subcontractor in the opinion of each respondent The final process of assessing risk to the decision sub-criteria is to make a multiplication between the probability and impact / risk impact on each decision subcriteria. The total results of these multiplications are shown in Table 5.

\section{Final Result to Selecting Subcontractor}

From the results of interviews with management from the company, the final evaluation comparison of subcontractors with the ANP method and risk assessment weighs 60:40. The $60 \%$ weighting assessment is based on the ANP method because the selection based on the ANP method takes into account the criteria that are important for subcontractor assessment, while the final value for risk assessment is $40 \%$ because the initial risk assessment can be prevented in the next process so that the risk value identified can be input for companies to take further action what will be done. After obtaining the value of the subcontractor assessment using ANP and assessment of risk, the final step is to determine the total value of the ratio between the Subcontractor Value with the ANP method compared to the value of the subcontractor based on the risk assessment. The Final Result, Subcontractor B get the highest score with 2,97 and second place 
The $6^{\text {th }}$ International Seminar on Science and Technology (ISST) 2020

July $25^{\text {th }}, 2020$, Institut Teknologi Sepuluh Nopember, Surabaya, Indonesia

Subcontractor A with 2,77 and third place is Subcontractor C with 2,66 (Figure 2).

\section{CONCLUSION}

Based on the results of research from the analysis of data in the previous chapter, it can be concluded that: (1) Appropriate criteria and sub-criteria in the selection of subcontractors in $\mathrm{XYZ}$ company is the highest weight value that affects the ANP process is in the bid price subcriterion with a weight of $17.13 \%$ in the price criteria and material specifications with a weight of $13.03 \%$ in the technical criteria that have the highest weight and is quite significant difference from the other weight values; (2) Criteria and subcriteria that influence the process of selecting subcontractors in XYZ Company are technical criteria with a weight of $38.89 \%$, price criteria $21.85 \%$ and internal criteria with a value of $19.32 \%$. Whereas the highest decision of the five highest decision sub-criteria is the price price sub-criteria weighing $17.13 \%$, then specifying the material with a weight of $13.03 \%$, the method of implementation with a weight of $9.65 \%$, the implementation period of $9.45 \%$ and finally the document / certification companies with a weighting of $7.04 \%$; (3) The results of a comparative analysis of the selection of subcontractors using the ANP = Risk Assessment method with the previous selection method at XYZ Company are the same, the chosen subcontractor with the highest value is Subcontractor B; (4) The results of the risk assessment analysis show that subcontractor $\mathrm{C}$ has the highest risk value, compared to subcontractor $\mathrm{B}$ risk and the risk of subcontractor A has the lowest risk value.

\section{REFERENCES}

[1] Soeharto, Manajemen proyek dari konseptual sampai operasional, Jakarta: Erlangga, 1995.

[2] A. E. Cengiz, O. Aytekin, I. Ozdemir, H. Kusan and A. Cabuk, "A Multi-Citeria Decision Model for Construction Material Supplier Selection," Procedia Engineering, 2017.

[3] T. L. Saaty, "The Analytic Network Process: Decision Making with Dependence and Feedback," 1999.

[4] R. C. Walke, "An Approach To Risk Quantification In Construction Project Using EMV Analysis," International Journal of Engineering Science and Technology, vol. 3, 2011.

[5] D. J. Watt, B. Kayis and Willey, "The Relative Importance of Tender Evaluation and Contractor Selection Criteria," International Journal of Project management, vol. 28, pp. 51-60, 2010. 